\title{
TED TALK TECHNOLOGIES AND THE METHOD OF "SIMULATION" IN MARINE LAW SPECIALISTS' ESL CLASSROOM OF HIGHER EDUCATIONAL INSTITUTIONS
}

\section{ТЕХНОЛОГІї TED TALК ТА МЕТОД «СИМУЛЯЦІї» У НАВЧАННІ АНГЛІЙСЬКОї ЯК ІНОЗЕМНОї МОВИ МАЙБУТНІХ ФАХІВЦІВ МОРСЬКОГО ПРАВА У ВИЩИХ НАВЧАЛЬНИХ ЗАКЛАДАХ}

УДК 378.147:004

DOI https://doi.org/10.32843/2663-

$6085 / 2021 / 34-2.21$

\section{Ocheretna O.Yu.,}

Candidate of Pedagogical Sciences,

Associate Professor at the English

Language Department № 2

National University

"Odesa Maritime Academy"

Gonchrenko M.H.,

Senior Teacher at the English

Language Department № 2

National University

"Odesa Maritime Academy"
The article is devoted to one of the current problems of training future specialists in maritime law in higher education. Current requirements and conditions dictated by the modern labour market, foreign employers, and modern methods used in the communicative and self-studying organization in learning English for future specialists in maritime law in higher education. In particular, the essence of such concepts as the development of communication activities, the self-studying organization, the use of various modern methods including TED Talks, the method of "simulations" in ESL classes. New trends in the use of TED Talks technologies and the method of "simulation" in the development of communication skills, its effectiveness and relevance are studied. The urgency of this problem and the lack of theoretical and methodological development of forms and methods of self-studying organization, the development of communicative activities of university students, as well as the prospects for its development are revealed in the research. The state of coverage of the self-studying organization and modern methods of developing students' communication skills at the theoretical and methodological level among modern scholars and teachers is analyzed and the optimal forms and methods of students' self-studying organization as a type of educational activity aimed at forming student cognitive abilities are determined. The main task of the self-studying organization of students is outlined as the use of traditional and innovative forms and methods of teaching, which would complement each other, be a single system that can be adapted to the specifics of the educational process in a particular higher education institution training of highly qualified specialists.

Key words: communicative activity, ESL class room, marine law, method of "simulation", selfstudying organization, TED Talks technologies, training of future specialists.

Стаття присвячена одній з актуальних проблем підготовки майбутніх фрахівців морського права у вищих навчальних закладах, актуальним вимогам і умовам, які диктують сучасний ринок праці й іноземні роботодавці, та сучасним методам, які застосовуються в організації комунікативної та самостійної роботи під час вивчення англійської мови майбутніх фрахівців морського права у вищих навчальних закладах. Зокрема, розкривається сутність таких понять, як «розвиток комунікаційної діяльності», «організація самостійної роботи», уживання різних сучасних методів, як-от концепція TED Talks, метод «симуляцій», на заняттях з англійської мови. Вивчаються сучасні тенденції застосування технологій TED Talks ma методу «симуляції» під час розвитку комунікативних навичок, їх ефективність і актуальність. Зазначається актуальність досліджуваної проблеми та недостатність теоретичної та методичної розробленості фрорм і методів організації самостійної роботи та розвитку комунікативної діяльності студентів закладів вищої освіти, а також перспективність ї розвитку.

Аналізується стан висвітлення питань організації самостійної роботи та сучасних методів розвитку комунікативних навичок студентів на теоретико-методологічному рівні серед сучасних науковців та педагогів, визначаються оптимальні форми та методи самостійної роботи студентів як виду навчальної діяльності, спрямованого на формування пізнавальних здібностей студента. Також у статmі головним завданням організації самостійної роботи студентів виділяється використання традииійних та інноваційних фрорм і методів навчання, які б доповнювали одне одного та становили єдину систему, яку можна адаптувати до особливостей навчального процесу в конкретному вищому навчальному закладі з метою оптимізації навчання та підготовки висококваліфікованих фрахівців.

Ключові слова: розвиток комунікативної діяльності, організація самостійної роботи, технології TED Talks, метод «симуляції», підготовка майбутніх фрахівців морського права.
Problem statement. In the vortex of the development of a modern society, higher education should train not just a highly educated specialist, but a specialist with non-standard creative thinking. Under the terms of the Bologna Declaration, the share of direct student information is reduced in the learning process and the use of interactive forms of student work under the guidance of a teacher is expanded. Full-fledged independent work of a student in laboratories, reading rooms, participation in scientific researches forms the modern expert capable of applying meaningful information practically. In higher education, there is the question of the adaptation to the conditions of higher education, where the share of the independent work, self-organization, self-education increases significantly.

The organization of student's independent work becomes one of the priority directions of the work of a teacher in an educational institution of any level. Students can organize independent work in differ- 
ent ways and for different purposes. In our opinion, it is necessary to organize the independent work of students with the accumulation of knowledge, skills and abilities, provides an opportunity to develop the creative abilities of students of higher educational institutions.

Students should not only take an active part in the process of perception and assimilation of knowledge but also have their position on them, be able to apply what they have learned practically, correlate the results with the prospects of their future profession.

Theoretical framework. At the theoretical and methodological level, the problem of organizing independent work of students is covered in the works of many teachers and scholars: A. Aleksyuk, S. Arkhangelsky, Y. Babansky, S. Shikhalova, V. Bezpalko, P. Podkasisty; psychologists: A. Petrovsky, O. Leontiev, K. Platonov, S. Rubinstein; methodists: O. Demchenko, I. Dychkivska, A. Smolkina, O. Bilyaeva, L. Palamar, M. Pentilyuk, K. Plysko. However, the lack of theoretical and methodological development of forms and methods of organizing independent work and development of communicative activities of university students, as well as the prospects for its development led us to choose the topic of our study.

Unsolved problems under consideration. The urgency of this problem is due to the insufficient theoretical and methodological development of forms and methods of organizing independent work of university students, as well as the prospects for its development. The problems of developing communication skills of future specialists in maritime law and the use of modern methods in ESL classes in higher education are not fully resolved.

The study aim. The purpose of our study is to determine the optimal forms and methods of independent work of students as a type of educational activity aimed at forming the cognitive abilities of a student, their focus on continuous self-education.

Main body. Independent work of students is one of the components of the educational process, and therefore, like all its components, is a system of organizational and didactic activities aimed at training in areas and specialities at relevant educational levels.

The organization of the independent work of a student becomes one of the priority directions of the teacher's work in an educational institution of any level. Students can organize independent work in different ways and for different purposes. In our opinion, it is necessary to organize the independent work of students so that it, together with the accumulation of knowledge, skills and abilities, provides an opportunity to develop the creative abilities of students of higher educational institutions.

Traditionally, the students' independent work of is carried out in the following forms [1]:
- individual (abstract reports, course papers, independent research work, individual consultations, competitions, etc.);

- group (project and problem-based learning, collaborative learning, game design, group consultations, optional classes);

- mass (project training, programmed training).

In modern pedagogical practice, among the most effective methods of the students' independent work, contributing to the individualization and intensification of the educational process, should be noted [2, p. 132]:

- problem-searching methods;

- the method of project training;

- the methods of collective mental activity;

- the method of application of the newest information and communication technologies in training.

We focus not on a comprehensive consideration of these methods but on the analysis of the basic principles, rules of formation and use of the most effective methods for organizing independent work of students.

Analyzing the given classification, it is necessary to note such characteristic feature, as conditionality. Thus, according to A. Smolkin, most methods of active learning have a multifunctional significance in the learning process [3, p. 32].

Problem-searching methods are aimed at activating the cognitive activity of students. The use of these methods encourages students to conduct independent research, increases the motivation for further work, promote the development of logical thinking, as a consequence, the development of the creative independent activity of students. The ideal result of learning problem-solving methods is the development of skills to apply all components of the system of these methods in the development and relationship.

Another modern method of communication skills' development, called TED Talks. TED Talks is a world-renowned conference that spreads ideas worth hearing. One speech lasts up to 20 minutes and contains a relevant and original idea. However, a successful speech is not just a decent idea, but also a convincing and rich language, usually English. That's why since 2015, National Geographic Learning has been creating English textbooks with elements of TED Talks. One of the textbooks, Keynote, is based on TED Talks.

According to the analysis of the classes of Keynote Intermediate (British English) students master the topic "Work", Grammar present tense (Present Simple), several types of questions and learn to write business letters.

A lesson starts traditionally with a warming up, information about the speaker. This is a firefighter Mark Bezos, the questions to his short biography, a test how well students understand the text and refresh the memory of words they already know. Then the time for 
new vocabulary comes. First, the textbook introduces the words that will sound in the speech. Students process them in context and then review a TED Talk.

This TED Talk lasts about 5 minutes. After asking questions about the general understanding of TED Talk, students move thorough. They are offered three exercises, each of which is dedicated to a specific part of the video. In particular, students should answer questions and complete sentences.

After working on the video, the new words are reinforced with vocabulary exercises in the context (for example, you need to choose the right meaning of a words), as well as tasks for critical thinking and presentation skills.

Critical thinking exercises involve speech analysis. How does the speaker present his opinion? What arguments does he make? How do you comment on this TED Talk online? Students use English in practice: analyze information, express their opinions, and comment on the ideas of peers.

Presentation skills are an important part of learning and working. Thanks to Keynote, students train and prepare a presentation and submit information in English. Each section contains tips for preparing and conducting a presentation. They are accompanied by examples from the revised speech because the speakers of TED Talks can capture the audience $[6 ; 7]$.

After discussions and videos, grammar material is introduced. First, students work with infographics, which is accompanied by exercises. Grammar rules are given later - by this time a student already knows why and where they are needed and better perceive them.

Speaking exercises are usually marked 21'st Century Outcomes. It denotes the skills needed by a man in the twenty-first century.

These modern skills are closely related to the topic of the lesson - in our case, work. Thus, in one of the tasks students have to evaluate the information correctly, in the other - to read the article about skills and analyze their own set of skills. The third task trains the ability to write official letters and at the same time teaches the right questions about an interesting vacancy. So the use of English is closely related to real life. Students understand that they are not learning dry word lists or unintelligible grammar. Everything is immediately accompanied by topical examples and relevant exercises.

A set of exercises in the Workbook is added to the lesson in Student's Book. In general, Keynote is offered in two versions: American and British English. Textbooks are divided into levels according to the CEFR classification - each contains relevant topics, vocabulary and grammar. Yes, at the Intermediate level it is about working days, and at the Upper-Intermediate level, students learn to talk about career and personal development.
Keynote is not the only National Geographic Learning development to involve TED Talks. There are now four series of textbooks that use TED Talks as an aid or provide training in certain skills with.

TED Talks are world-changing ideas and speakers that capture not only the audience but millions of viewers on YouTube. Here is a reason to use it as a learning tool and prove that English is interesting and practical $[5 ; 7]$.

Another modern method of developing of communication skills of future specialists in maritime law is modern technologies in education that are professionally-oriented to foreign language teaching, project work in teaching, application of information and telecommunication technologies, work with educational computer programs in foreign languages (multimedia system), distance technologies in foreign language teaching. In teaching ESL to students of humanities, you can successfully apply the method of simulation. In cybernetics, this term is used to model and simulate reality. The training is about a variety of simulation games that allow students to practice their skills, apply knowledge to solve a problem in the so-called "safe environment", which simulates real situations, such as working in a company. The simulation allows students trying themselves in a certain role - the head, the president of the company, to explore the system of a particular enterprise.

The participants of a game are given certain tasks - to conclude a contract, hold negotiations, etc. Simulations are characterized by a high degree of interest of participants who fully immerse themselves in the game, embody their role, and care about the result of work, because the team spirit, the speed of decision-making depends on the overall result of the game. Thanks to the simulation, the skill of strategic planning are formed in students, the ability to work in a team is developed. Simulations organize students' knowledge; prepare them for the need to make quick and motivated decisions in future activities. Simulations have already become widespread. Learning with the help of simulations was developed and proposed by English and French scientists (E. Narbut, K. Jones, E. Christopher, J. Richards, etc.) [ $1 ; 2$, p. 47; 3, p. 145; 4]

Simulation is the movement of people into "fictitious, simulating real" situations to learn or get an assessment of the work done, it is learning by action or in action.

The simulation develops the response speed; develops the ability to evaluate information and dispose of it, helps to develop the ability to solve professional problems.

Next, we will give an example of a lesson in which we used the method of "simulations". The topic was chosen in advance, the roles were distributed so that all students could prepare for this game. The theme of this game is "How to get a bank loan?". The essence 
of this game was how three groups of young students from a small town, who do not have some experience in doing business, decide to take a loan from a local bank. They all wrote an appeal to the bank's management asking them to provide them with money to start their new business. The task of the bank employees is to conduct interviews with each group of young people, to prepare certain questions to find out which of them has prepared their previous business plan as competently and successfully as possible.

The task of young borrowers is to prepare as many financial arguments as possible that could convince creditors and get a loan.

So, the roles were as follows - a young manager an assistant, a bank employee who deals with lending to businessmen and his assistants, three groups of young start-ups, each of whom has a desire to start their own business. The first group would like to open their IT specialized store.

The second group would like to buy an existing business related to the sale of pizza and its delivery to a specific address. The business is very profitable and most of the townspeople have visited and visited this pizzeria and therefore the new owners of the institution will not change the name and address of this institution.

The third group of students, who already provide consulting services to the public and give advice on what computer equipment to buy and how to create a website. This group wanted to buy more computers to be able to build more programs [7].

Thus, the teacher assigns all the roles in advance and composes the script so that all students are involved in the game. The next lesson was the game itself.

After the game, students shared their impressions, discussed the most exciting moments, exchanged thoughts and ideas about the next lesson game.

Conclusions. Thus, the independent work of students is the main form of organization of education, which includes various types of individual and collective learning activities, which are carried out in a classroom and extracurricular activities, taking into account individual characteristics and cognitive abilities of students under the guidance of a teacher or without the direct participation. In the context of our study, independent work is defined as a type of educational activity aimed at forming the cognitive abilities of a student, their focus on continuous self-education. Independent work of students is an important component in the training of a qualified specialist, competitive in the labour market, capable of competent professional activity at the level of world standards.

Organizational features of independent work are: availability of tasks for independent work; providing special time for their implementation; planning methods, tools and forms of independent work; students' educational activities (collective or individual), their activity in this case; self-control and current control; management of this work by the teacher; availability of expected results.

Thus, the main task of organizing independent work of students is to use both traditional and innovative forms and methods of teaching, complementing each other, would be a single system that can be adapted to the specifics of the educational process, in a higher education institution to optimize learning and training of highly qualified specialists.

\section{REFERENCES:}

1. Демченко О. Дидактична система організації самостійної роботи студентів. Рідна школа. 2006. № 5. C. 68-70.

2. Дичківська І. Інноваційні педагогічні технології. Київ : Академвидав, 2004. 351 с.

3. Смолкин А. Методы активного обучения. Москва : Высш. шк., 1991. 290 с.

4. Шихальова С. Впровадження нових інформаційних технологій у процес вивчення іноземних мов. Педагогічний пошук. 2002. № 4. С. 27-28.

5. Lowe A. TED Talks as authentic listening materials: turning points and near-death experiences. Global Journal of Engineering Education. 2002. Vol. 6. № 1. P. 91-100. URL: http://blog.tesol.org/tedtalks-as-authentic-listening-materials-turning-pointsand-near-death-ex-periences/ Reimer M.J. English and communication skills for the global engineer.

6. TED Talks for ESL Students Every Teacher Should Use. URL: https://www.fluentu.com/blog/educatorenglish/ted-talks-for-esl-students/.

7. Young P. 3 Ways to use TED Talks with ELs. URL: https://www.empoweringells.com/ted-talks/. 